\title{
Courtyard in Contemporary Multi-Unit Housing: Residential Quality with Sustainability and Sense of Community
}

\author{
Hatice Kalfaoğlu Hatipoğlu ${ }^{1}$ \\ ORCID: 0000-0002-0716-7431
}

\author{
Shorouk Mohammad ${ }^{2}$ \\ ORCID: 0000-0003-4577-8126
}

\begin{abstract}
Courtyard is an important element, a representation of success in social sustainability and architectural quality. The philosophy of courtyard within the urban fabric is an expression of cohesion and community. While courtyard typology sustains in some urban patterns with an adaptation, this continuum has not been achieved in some contexts. Vernacular architecture had to face several challenges and courtyard typology was replaced with profitable mass housing without previous spatial codes at the expense of the human needs and values that guide design decisions. In this context, this paper aims to provide sustainability of the courtyard in contemporary housing with an adaptation such as after-war Syria redevelopment in order to provide a socio-spatial quality and sustainability. The study reviews the sense of courtyard for residential areas and examines the reasons for the absence of this element in contemporary multi-unit housing. Moreover, this study analyses housing examples with courtyard from different periods of Vienna with cause-effect relationship. The study concludes that Vienna has provided a wealth of innovative experimentations of courtyard in contemporary housing successfully which can lead new housing dynamics in urban contexts such as Syria.
\end{abstract}

Keywords: Courtyard, housing quality, social sustainability, Vienna Housing, urban morphology, sustainability, architectural codes.

\footnotetext{
${ }^{1}$ Asts. Prof., Ankara Yıldırım Beyazıt University, E-mail: hhatipoglu@ybu.edu.tr

2 Ankara Yıldırım Beyazıt University, E-mail: shurouk.mohammad@gmail.com

idealkent @ Kent Araştırmaları Dergisi (Journal of Urban Studies) 


\section{Günümüz Çok Katlı Konut Alanlarında Avlu: Sürdürülebilirlik ve Güçlü Topluluk Hissi ile Oluşturulan Kaliteli Yaşam Alanları}

\author{
Hatice Kalfaoğlu Hatipoğlu ${ }^{3}$ \\ ORCID: 0000-0002-0716-7431
}

*

\author{
Shorouk Mohammad 4 \\ ORCID: 0000-0003-4577-8126
}

\section{Öz}

Avlu, sosyal sürdürülebilirlik ve mimari kalitedeki başarmnn bir temsili olarak önemli bir tasarm unsurdur. Kent dokusu içerisinde avlu, felsefik olarak sosyal uyum ve topluluğun bir ifadesidir. Avlu tipolojisi bazı kent morfolojilerinde bir uyarlama ile varlığın sürdürürken, bazı bağlamlarda bu süreklilik sağlanamamıştır. Çeşitli dönü̧̧ümlerle konut çeşitli zorluklarla yüzleşmek zorunda kalmış ve avlu tipolojisi, tasarım kararların yönlendiren insan ihtiyaçları ve değerlerinin yok olması pahasina ve rant uğruna kopukluğa uğrayan mekansal kodlarla farkl konut biçimlerine evrilmiştir. Bu bağlamda, bu makale, sosyo-mekânsal bir kalite ve sürdürülebilirlik sağlamak için savaş sonrası Suriye güncel çok katl konut alanlarının yeniden yapılandırllması gibi bağlamlarda avlu tipolojisinin adaptasyonla devamının sağlanmasına katkıda bulunmayı amaçlamaktadır. Çalışma, konut alanları için avlu olgusunun önemini vurgularken, çă̆daş konutlarda bu unsurun kayboluşunun nedenlerini de ortaya koymaktadır. Ayrıca, bu çalı̧ma, bir mimari kod olarak avlu tipolojisini yaratıcı bir süreklilik ve adaptasyon ile ortaya koyan Viyana şehrinin farkl dönemlerine ait avlulu konut örneklerini neden-sonuç ilişkisi ile analiz etmektedir. Çağdaş konutlarda başarlı ve yaratıcı avlu deneyimlerinin ve bu sürdürülebilirliğin somut olarak ortaya konmast ile Viyana'nın, Suriye gibi bağlamlarda güncel konut dinamiklerine yön verme potansiyelini açığa çıkarırken nasıl sağlanabileceğ $i$ konusunda rehber niteliğindedir.

Anahtar Kelimeler: Avlu, sosyal sürdürülebilirlik, Viyana, konut tasarmm, kent morfolojisi, sürdürülebilirlik, mimari kodlar

\footnotetext{
${ }^{3}$ Dr. Öğr. Üyesi, Ankara Yıldırım Beyazıt Üniversitesi, E-mail: hhatipoglu@ybu.edu.tr

${ }^{4}$ Ankara Yıldırım Beyazıt Üniversitesi, E-mail: shurouk.mohammad@gmail.com

idealkent @ Kent Araştırmaları Dergisi (Journal of Urban Studies) 


\section{Introduction}

Through history, housing forms have evolved within different styles and various structures to keep pace with the social, cultural, and economic needs of society. People translated their religious, environmental, social, and economic functions parallel to the transformations in architecture spaces. For instance, the transportable tent was an innate response to the nomadic lifestyle. Every society created its architectural forms as an inherent product of environment, and people's culture (Salman, 2018). In this context, the concept of a courtyard house emerged both as a unit and as part of a settlement fabric that is congenial to all humanity (Petruccioli, 2007). The courtyard house typologies are possibly the most enduring and widespread housing type in history, as it was founded in antiquity and in modern times, in most world regions, in different climates and cultures, and in a range of different building materials (Abass, Ismail, \& Solla, 2016 ;Edwards, Sibley, Hakmi , \& Land, 2006).

In Syrian old cities, courtyard houses were built to fit in socially, functionally, environmentally, as well as architecturally, people's needs along with their livelihood. They grew organically as a community-sustaining architecture (Al-Sabouni, 2017). Since the middle of the twentieth century, the vernacular architecture in Syria had to face several challenges with the adaptation of European standards in construction and planning at architectural and urban levels. In the meantime buildings of similar cement blocks ignoring the context have been established without considering the environmental, functional, and aesthetic aspects, and the characters of the Syrian society. This shift in housing patterns has turned into urban and social decline. In this regard, the current conditions of Syrian architecture and the extensive destruction that resulted from the war, present an opportunity to reconsider the residential projects in order to provide a conscious and responsible approach for good quality sustainable urban development in post-war Syria. Because it is crucial to protect some socio-spatial codes against the deterioration of a modern built environment that ignores cultural and social aspects and identity (Pomeroy, 2020)

On the other hand, the successful housing experiences of other countries in terms of sustaining the courtyard patterns to the current environment and era;providing quality of life for inhabitants have a wealth of knowledge worthy of consideration. Therefore, it is important to follow these experiences to develop innovative solutions that can fit into Syrian context. As Jane Jacobs (1992, p.188) said, "new ideas must use old buildings". It is necessary to 
analyse the codes in architecture in order to understand and make sense of the philosophy to be sustained, the choice of style and design decisions(Hatipoglu \& Koç Aytekin, 2020). Then, the question then come to the fore how to develop and transfer the idea of traditional courtyard housing to the contemporary urban design model for post-war Syrian Housing in order to provide sustainable communities that had provided a sustainable architecture in Syria in the past in terms of social, cultural and ecological aspects.

Although the importance of the courtyard has been conceptualized in several studies, it is still lacking how to adapt tratidional courtyard house -most of which is low-rise- to contemporary housing design by adapting to current conditions and requirements of multi-unit housing in cities, espacially in eastern countries such as Syria. Therefore, the study contributes to demonstrate and support theory with concrete cases with successful contemporary examples of multi-unit housing with courtyard. In this context this paper aims to provide sustainability of courtyard idea in Syrian housing which has a quality in terms of socio-spatial aspects that characterize activity-patterns and environments. The paper is not a call to rebuild courtyard houses exactly the same in their old form, but rather to apply a modern courtyard housing typology for the future by integrating them with modern development/technology and changing requirements to enhance the quality of sustainable urban life. This paper focuses on the advantages of the revitalization of the courtyard housing typology to the future urban design in Syria, not just to revive the cultural identity or a salt urban morphology in architecture, but to ensure social sustainability and contemporary architectural quality in multiunit housing, which will contribute to create a better design for future (postwar) urban environments. The study reviews the meaning of traditional courtyard house in Syria in terms of social and morphological characteristics and introduces main design factors related to its historic form. Then, it analyses the reasons for the absence of this element in modern Syrian housing typologies. Moreover this study reveals how these traces, which are not merely images, can be adapted to today's conditions within the framework of cause and effect relationship with concrete examples of the sustaining reuse of the courtyard house in urban patterns. An analysis of concrete practices from Vienna has been conducted, which demonstrates the courtyard continuum as an architectonic code in urban pattern consistently. At the end discussions and recommendations have been presented for the implementation of the courtyard typology with its qualities and advantages, in post-war Syria in order to provide a sustainable future in terms of social, cultural, and ecological aspects. 


\section{Syrian Courtyard Housing}

\section{The courtyard vision in Syrian Old Cities}

Courtyard housing in Syria first appeared three millennia ago influenced from the previous nomadic life with the addition of open spaces. This has been a satisfaction with a convenient inside-outside relationship. The reality is that the courtyard was a responsive typology to the social, cultural aspects in space configuration of old cities. People built courtyard houses, not in order to stand out, but to live in harmony parallel to their cultural and social perspective/structure (Al-Sabouni, 2017). Moreover,the social, traditional and religional indicators were strong parameters in giving meaning to the courtyard within the urban fabric. As the main focus is on the family's position and privacy seclusion with a minimal display of the occupant's social status to the outside world (Abass, Ismail, \& Solla, 2016). The importance of the courtyard as a functional element can be summarized with the words of Hasan Fathy (2010, pg 57) :"Yet, to the Arab especially, the courtyard is more than just an architectural device for obtaining privacy and protection. It is, like the dome, part of a microcosm that parallels the order of the universe itself".

Additionally, the courtyard as an element of the urban pattern collected different social classes and different religions in heterogeneity, but in a harmony which was built by people themselves as an emergent phenomenon . This model of housing has been an urban fabric in which rich and poor, Mus$\mathrm{lim}$ and Christian were woven together in unostentatious, closely-knit houses (Al-Sabouni, 2017). This sense of neighborliness cultivated a life of tolerance, peace and coexistence which has the potential to provide sustainable communities.

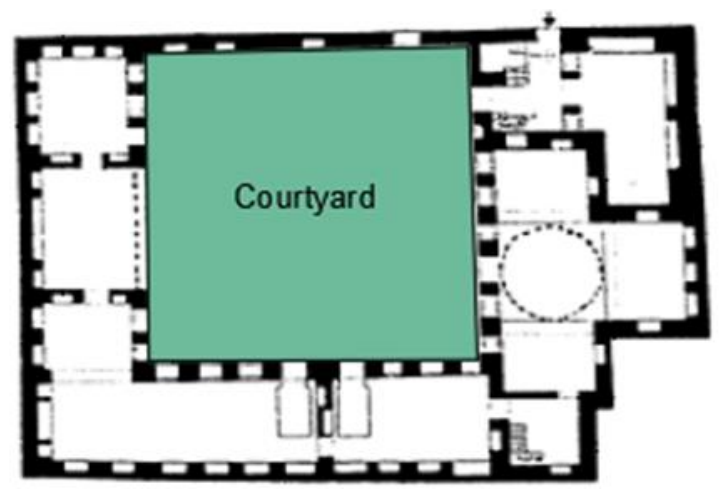

Figure 1. The traditional Syrian courtyard plan (Edwards, Sibley, Hakmi, \& Land, 2006) 


\section{Social and culture characteristics of Courtyard Housing regarding sustainable communities}

\section{a) The privacy considerations}

The Islamic belief and traditional thoughts shaped the social rules and lifestyle of the Syrian community, which was reflected in physical features of traditional courtyard houses. Therefore, the privacy of family life is one of the important needs that a Syrian courtyard house has sought to achieve. The design of the house is mainly oriented toward the central courtyard, there is no view from street or other surrounding houses, which provides a convenient privacy. Even though the central courtyard is an open space, it maintains a protection from prying eyes, as it cannot be seen from outside (Zein Alabidin, 2010). In fact, the courtyard forms a specific space, which has many advantages in the creation of a spatial and visual privacy, an intimate world for peaceful and secluded spaces.

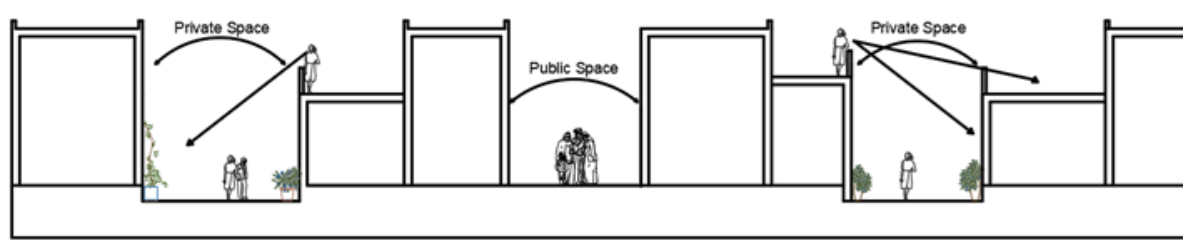

Figure 2. A section showing how courtyard provide privacy, developed by authors depending on Edwards, Sibley, Hakmi, \& Land (2006)

\section{b) Social and cultural considerations}

The old Syrian society tends to be an extended family in which many families live together and help each other. Normally the community is based on collaboration and support to maintain strong family and neighbourhood ties (Zein Alabidin, 2010) .Socially, the courtyard came consistent with this type of society and cultural mentality. Moreover, regardless of size, the courtyard provides an extension of the house providing green space for daily use of the family or social gatherings for specific events . Also, they contributed to practicing the social rituals according to the prevailing social relations in the community. Thus, the courtyard has played a main role in everyday life and social interaction. The family member has used to depend on courtyard as space in many social functions: 
- Private space: as it is a place for daily life activity (e.g., eating, sitting with family, cooking, workspace)

- Collective space: for guests and relatives such as religious ceremonies and wedding celebrations with folk music bands, in addition to open space for entertaining close friends like weekly female parties (Zein Alabidin, 2010).

- Safe space: especially for kids to play within parent's close supervision (Lee \& Park, 2015)

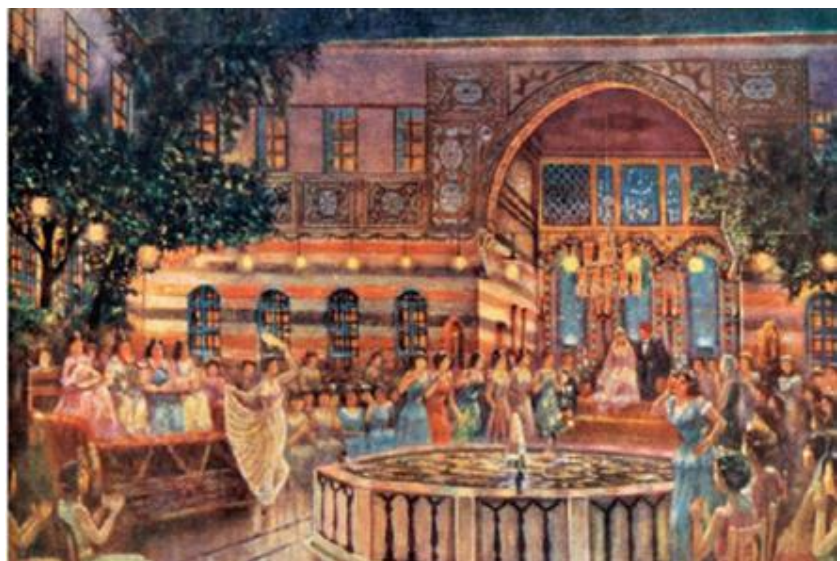

Figure 3. The traditional Syrian wedding ceremony in courtyard house drawing by Mohammad Nazir Baroudi (Al-Najm,2015)

\section{c) Environmental considerations}

The majority of Syrian cities are located in an arid subtropical climate. The main climatic features are the significant difference between hot days and very cold nights. Therefore, the common design solution for such a climate has usually been courtyard housing. It is an environmentally sustainable building in terms of providing a thermally comfortable area for living, such as allowing more sunlight penetration and natural ventilation (Taleghani, 2014; Aycam \& Varshabi, 2016). Courtyards have generally the ability to achieve thermal comfort to the residence as it is worked as a microclimate modifier (Abass, Ismail, \& Solla, 2016; Aycam et al., 2020). In addition, the garden of the courtyard appeals to the senses. This garden is often based upon Islamic philosophy of description of paradise. The garden mainly consists of two categories: Citrus and other fruit trees, flowers give scent and bouquet, both give color and form, and water invites contemplation (Edwards, Sibley, Hakmi, \& Land, 2006). 


\section{d) Hierarchy of Public and private space in the traditional urban city}

The urban fabric in old cities followed a clear and specific pyramid hierarchy from public to private space (Hassan \& Resen, 2018). Old city`s urban fabric consists of two basic elements: streets and courtyard houses. It is crucial to understand the intimate relationship between these two fundamental components in order to understand urban morphology. The courtyard housing, which was sharing common walls with other units, does not have any public space within. Therefore, all the interior spaces are private within the domain of the inhabitants.

Moreover, the narrow alleys, which eventually poured into the houses considered within the domain of the house. They worked as a semi-private space, which didn't allow strangers to use or stand nearby. It helps them to take control and security of their neighborhoods to protect from strangers and to reduce crime. Moreover, these blind alleys played a main role in social interaction as they were a semi-public or semi-private space for women to meet and interact with other neighbors (Nikeghbali, 2017). In addition, a safe place for children to play and meet with other children.
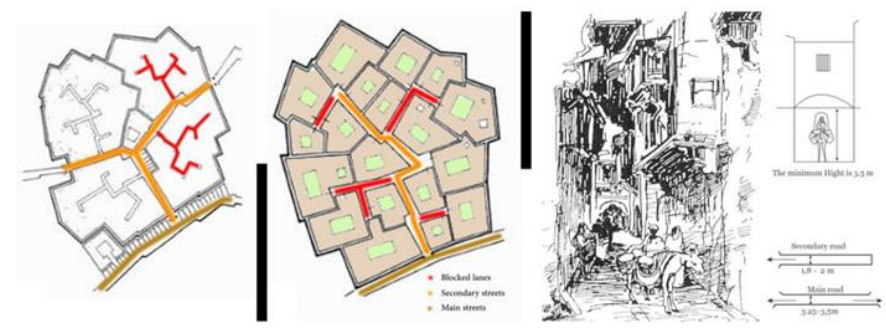

Figure 4. The specific pyramid hierarchy from public to private space in old cities (Mansour, 2015)

\section{Current Urban Transformations and the Absence of Courtyard in Syrian Housing}

The arrival of modernization has had an adverse effect on current Syrian housing architecture. From the nineteenth century to the turn of the twentieth century, there were many architectural turning points in Syria (Kandakji, 2013). The application of multi-story dwelling types with the staircase access system constituted a major part of the local housing stock in urban areas in Syria. Although, modern buildings are seen as improving living conditions in terms of providing main services like proper sanitation, electricity, etc. The negative influence is to bypass the culture and the architectural and urban identity of the local community. It was disconcerting to see that traditional courtyard dwelling typology was replaced with profitable models based on 
some technical innovation without any traces from previous spatial codes at the expense of the human needs and values that should have guided design decisions. Moreover, Architects have rarely asked critical questions regarding the appropriateness of form with regard to social and cultural conditions (AlJokhadar \& Jabi, 2016). The lack of a wider critical debate on the built environment in Syria had resulted in development practices that have produced serious long-term consequences (Edwards, Sibley, Hakmi, \& Land, 2006).
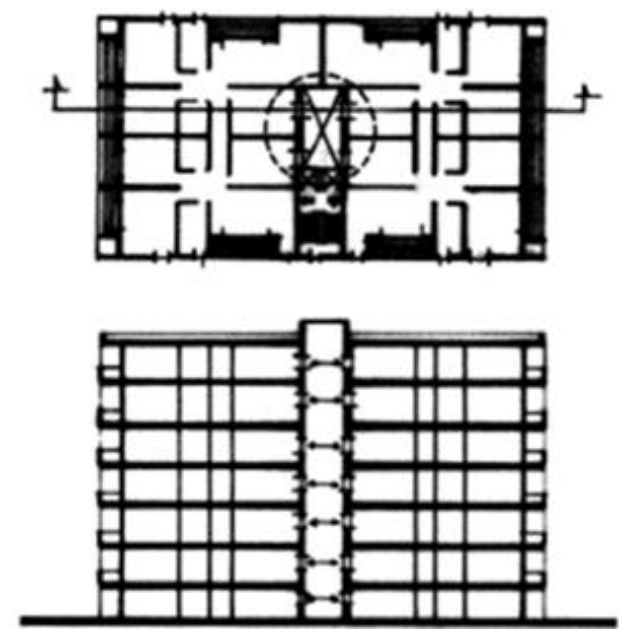

Figure 5. Multi-story dwelling types with the staircase access system (Edwards, Sibley, Hakmi , \& Land, 2006)

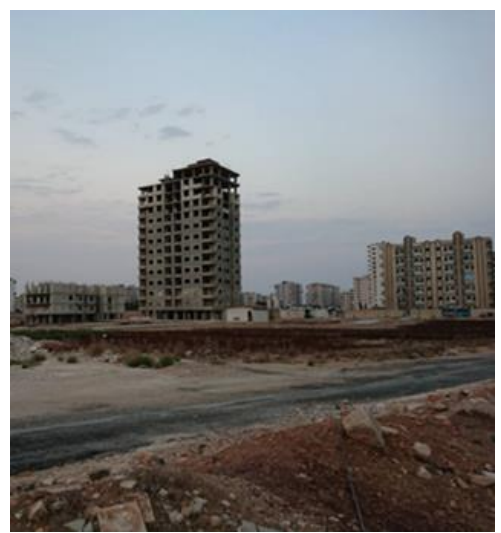

Figure 6. The contemporary prevailing housing pattern in Syria (Al-Sabouni, 2017)

In addition, with the decline of the courtyard typologies, the researcher in Syrian architecture notes how the courtyard opened to the sky was replaced by the window and balcony, which is not enough to ensure the same quality. 
These open outwards to satisfy a desire rooted in the soul, which is trying to reach an air outlet. The idea of the window in Syrian architecture was alien to society, as it did not come with the local culture. This window is often closed to preserve the privacy that is still sacred today in the local culture. It seems that people have also given up this semi-private space forcibly in favor of new spaces behind glass. The general sensibility was that houses seemed to create a wall of glass and cement separating them from the city and its residents. The unsuccessful attempts in planning lead to the shifts in the structure of the urban pattern/fabric. As the traditional environments have been obliterated by new urban patterns which break down the socio-spatial qualities.

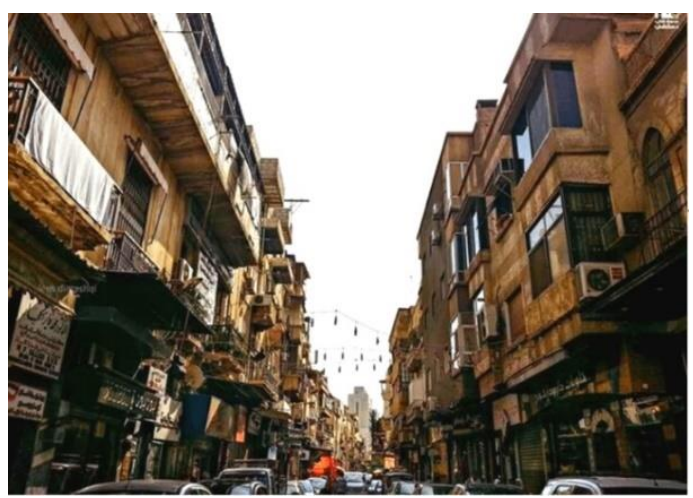

Figure 7. Closing the balconies with glass as if to protect their occupants from the intrusion of others (@lensdimashqi)

Moreover, the urban movement preferred to devour any public space or green elements in favor of more cement blocks, which courtyard has a successful inside-outside relationship. This has negatively affected people in terms of managing their social lives. This urban movement pressured people towards introversion to their homes. Unfortunately, this changing of Urban housing patterns has destroyed the historical city's established social and physical order, which has created a detachment among individuals and a general weakening of the social relationship between them (Al-Sabouni \& Scruton, 2016). These changes in housing models and urban pattern opened the door wide for the continuous decline we still suffer today (Al-Sabouni, 2017). From the identity perspective, it is a culturally poor residence from which a person cannot infer any meaning, it is based on monopoly and commodification. According to Makboul (2016), people were imprisoned within cement housing with the new urban pattern and form a gathering instead of achieving a sense of community. 
In conclusion, the current situation of the urban environment in Syria shows the importance of an urgent need to draw inspiration from identity and culture in formulating and shaping the city's morphology. In addition to taking inspiration from historical codes it is important to integrate them with modern developments and changing requirements. In this context, the contemporary architects and planners should reconsider how to create an architecture that not only contributes to the practical and economic aspects of people's lives, but also to their social, spiritual, and psychological requirements.

\section{Case Study: Analyse of Courtyard Housing typology in Vienna with the contemporary reflections}

After reviewing the Syrian courtyard houses and their characteristics, it is evident that the courtyard houses present many features that are still a requirement in terms of cultural, social, and functional aspects of the society. Over the past few decades, courtyard houses in Syria have experienced a decline as a result of urbanization, population growth, where they ceased to exist with the emergence of vertical architecture. At the same time courtyard housing has developed in all parts of the world by taking distinctive forms except for the Middle East (Edwards, Sibley, Hakmi, \& Land, 2006). Believing in the importance of courtyard housing in finding solutions to social and environmental problems created by modernity, it would be wise to examine the experience of courtyard housing models that have been applied in the Western World. Even though these models are not exactly the same with Syrian courtyard housing, their continuum and transfer of an architectural code over the years with the integration of modernism can demonstrate a good example. That is important for developing a courtyard typology with the previous code for post-war Syria urban recovery. This chapter is to review some examples of courtyard housing built in several periods of the 20th-century in Vienna in order to reveal the consistency in urban tissue.

\section{a) The vision}

The post-war period was particularly crucial for urban policies in Europe (Porotto, 2017), as the political change led to a rise in housing standards. The main concern of urban policies was the achieved two main goals: first, to provide collective spaces and green areas by public spaces. Second, to accomplish spatial and social justice, which means to eliminate the distinction between social classes to maintain a heterogeneous resident population (Po- 
rotto, 2017). As a result they focus on creating collective space as an intermediary space in-between the communal and private-which is a crucial feature of living together and the expression of democratic ideals. One of the urban and typological models that had appeared is the large courtyard block. Monterumisi \& Porotto (2017) indicates this approach as: "This large courtyard block was a convincing achievement in the process of reforming the urban perimeter block and it was a dominant and long-lasting model in some European cities.". The vision of housing was to provide "city as unitary expression of the collective identity», also to enhance sanitary conditions by adding any type of «amenities of life". Therefore, the adopted large courtyard blocks typologies made this vision possible. The apartments were realized as perimeter block developments or courtyard apartment buildings.

Vienna is a city in Europe which has left its mark in designing the collective space. It grew in a progressive and democratic way in housing policies. The housing dwelling in this city corresponds with the goals that have been adopted which are a better life and "living together". Even though these housing typologies in Vienna have been built for more than 100 years, they still have worked in the same way that they have been designed for . The philosophy of including the courtyard within the urban fabric in the morphology of the city was an expression of cohesion and community (Porotto, 2016).

\section{b) The environment consideration}

One of the characteristics of housing projects in Vienna housing is the adoption of high-quality standards which is clearly reflected in the climateand resource-friendly design. So, the main concern of urban policies was the achieved comfort by improving energy standards alongside adding the collective spaces and green areas (Alic \& Jadric, 2019). That has committed the government to adopt the motto of "Light, air, and sun", which committed the municipality to build these qualities into housing, public spaces, amenities, and services (Pelleteret, 2020). Moreover, the green and free spaces inside large courtyard blocks contribute to an ecological lifestyle. The available space provided by the implementation of large courtyard gardens which ensures a lot of advantages for housing in terms of low-tech sustainability such as ventilation, sun exposure, and the hygienic requirements (Porotto, 2016).

\section{c) Hierarchy of Public and private space}

The courtyard block shows a rational layout in its spatial organization and relationship with the urban fabric (Porotto, 2017). 
The city Vienna morphologic form of the urban block were linear semiperimeter blocks, mainly taking the shape of the land. The courtyard concentrates amid the urban blocks as open space. Bentley et al. (1985) emphasize that this style of block creates a distinct division between private and public spaces and maximizes the street's active edges. As a result, such a design creates security and livability of metropolitan regions (Bently, Alcock, Murrain, McGlynn, \& Smith, 1985).

This courtyard acts as a transition spaces between public space of the city and the inside of the housing. Whith this approach, the created hybrid spaces have been both parts of the public domain of the city and part of the private and communal space of the housing. They are multi-functional, multi-use features that serve as both housing and urban infrastructural nodes, disseminating the services and cultural facilities throughout the city. Eventually, the building with a courtyard reproduces the city while reallocating its spaces and amenities (Gibbons, 2019).

\section{d) The role of courtyard typology to sustain a sense of community, integ- ration, social cohesion}

Housing urban masses around a green yard has been the key to create new spatial and social relations among individuals. Moreover, the apartments were different in size, formation, and density, they have in common the employment of the large courtyard block model.

In terms of social sustainability, the large courtyard blocks have been assessed according to the everyday social aspects, such as social integration, and networking within the social infrastructure (Alic \& Jadric, 2019).

\section{Community building}

The vision of designing large courtyard buildings in Vienna is to provide a " new collective society and of a new idea of living together". So, to achieve this vision they sustained and interpreted architectural phenomenons and codes that can be read from the community. Tafuri (1985, p. 123) indicates that "the horizon of reference of realism inevitably assumes populist features" which emphasizes the importance of collectivity which helps to constitute a sense of community. A study has been conducted by Nasar\&Julian (1995) people find significantly more sense of community in the courtyard buildings, which is followed by the Vienna housing design.

Moreover, the design of a large courtyard form provides a shared open space, which works as a complementary of the housing units. The housing 
units that surround a communal courtyard, have a right to control or determine the activity taking place within it. This helps to develop community sense from an individual when he feels its rights in public space and safe space production. In addition, it increases the connection between neighbors who share the same public space. The adequate design of communal spaces offers a high degree of amenity and a strong sense of community (Alic \& Jadric, 2019).

\section{Social interaction in Contemporary courtyard}

The architectural form of the large courtyard has provided social sustainability with successful relationships. The courtyard, which includes practical aspects of everyday living, also involves sophisticated use of quality green and free spaces. The design of courtyard housing has been designed to offer a public space for social interaction of people, which is a set against a sociospatial division. The courtyard in contemporary urban blocks as a collective space has the ability to ensure spatial and architectural opportunities to realize a symbol of collective living with many social roles and functions in resident's lives. For instance, in Vienna, some buildings include within their yard some urban elements and facilities of the city (Porotto, 2016). Moreover, some courtyards include collective facilities connected to daily life such as rest areas, kindergartens, laundries, public baths, cooperatives, clinics, children's pools, common rooms, district libraries, etc. These common facilities and shared spaces aid in dissolving social barriers between the resident and wider communities. Additionally, the collective spaces of the courtyard are used as "outdoor living rooms". These usages of the courtyard as public and private aggregations of spaces reinforce the community identification of inhabitants to the courtyards (Porotto, 2016).

\section{The Sustainability of Courtyard Typology in Vienna: Concrete Examples}

The design approach of courtyard typology is still leading today's housing design approach following the same urban pattern with modern interpretations. This provides a wealth of typological experimentations in several ways with a harmony to the existing courtyard idea and urban pattern. .Figure 8 and 9: Sonnwendviertel Master Plan and 3d visualization showing the continuum of the urban pattern of old environments and new design. 


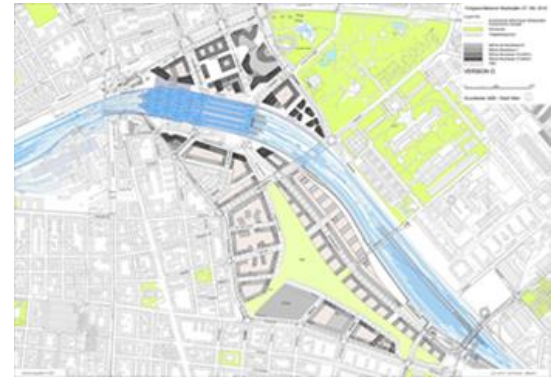

Figure 8.Sonnwendviertel Master Plan showing the continuum of the previous urban pattern

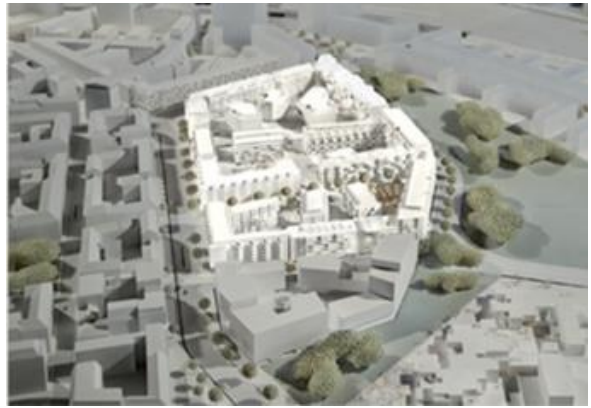

Figure 9. Sonnwendviertel 3d Visualisation showing the continuum of the previous urban pattern

This continuum has been one of the reasons that the city has succeeded in maintaining 'social peace' for more than a century and a process that has resulted in a successful culture of integration that continues to this day. Vienna has become an internationally renowned example of social integration, demonstrating that this is an absolute prerequisite for and an essential component of a fair, integrated, and sustainable city. (Alic \& Jadric, 2019)

Some projects with courtyards from different periods of Vienna have been analyzed base on some criteria. The projects after 1980s in the cases, ensure achieving one of the prescriptive four pillars of design social housing in $\mathrm{Vi}$ enna which is social sustainability and have been built as winners of competitions. The projects before this date are well-known housing with success and representation of their era. Their success is coming from having communal courtyards providing social quality/sustainability. All these projects emphasize the courtyard idea in design process as a design element. The cases in the analysis reveal this creative and innovative continuum in sequence and the sustainability of the courtyard until today: 


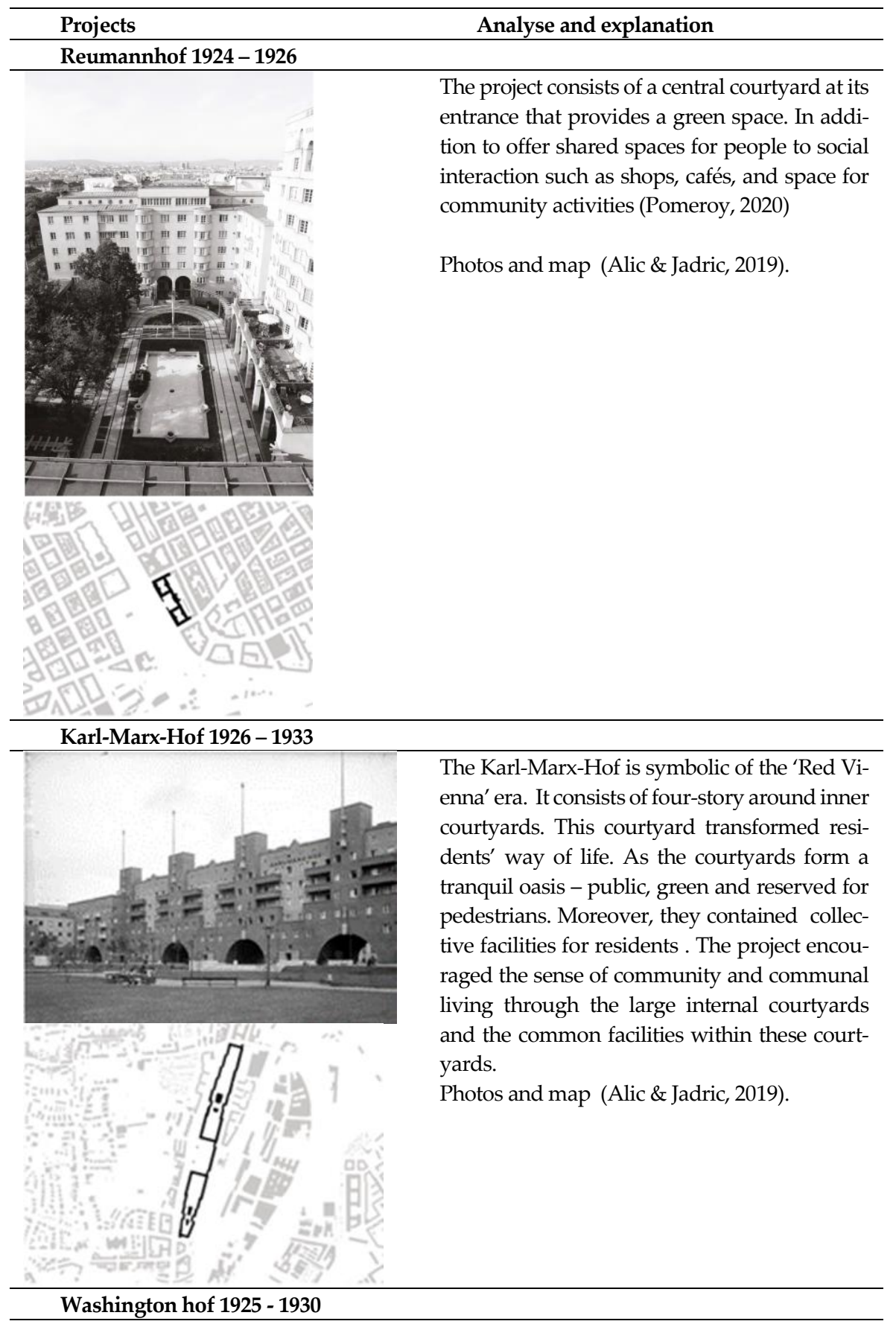




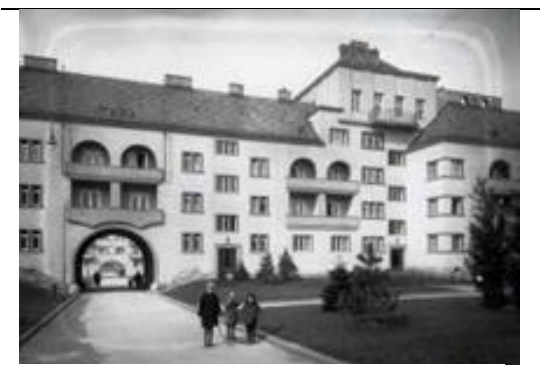

George Washington Hof was built as a symbol of social democracy. It consists of five courtyards lined next to each other with extensive green areas and crossed by two streets.

The project aimed to build an example in terms of continuity with the existing urban fabric in the city.

Photo (Wien Geschichte Wiki, 2021) , map (Fierlinger, 2016)

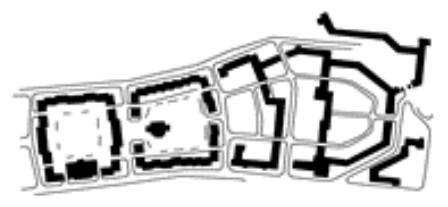

\section{Heinz-Nittel-Hof 1979-1983}

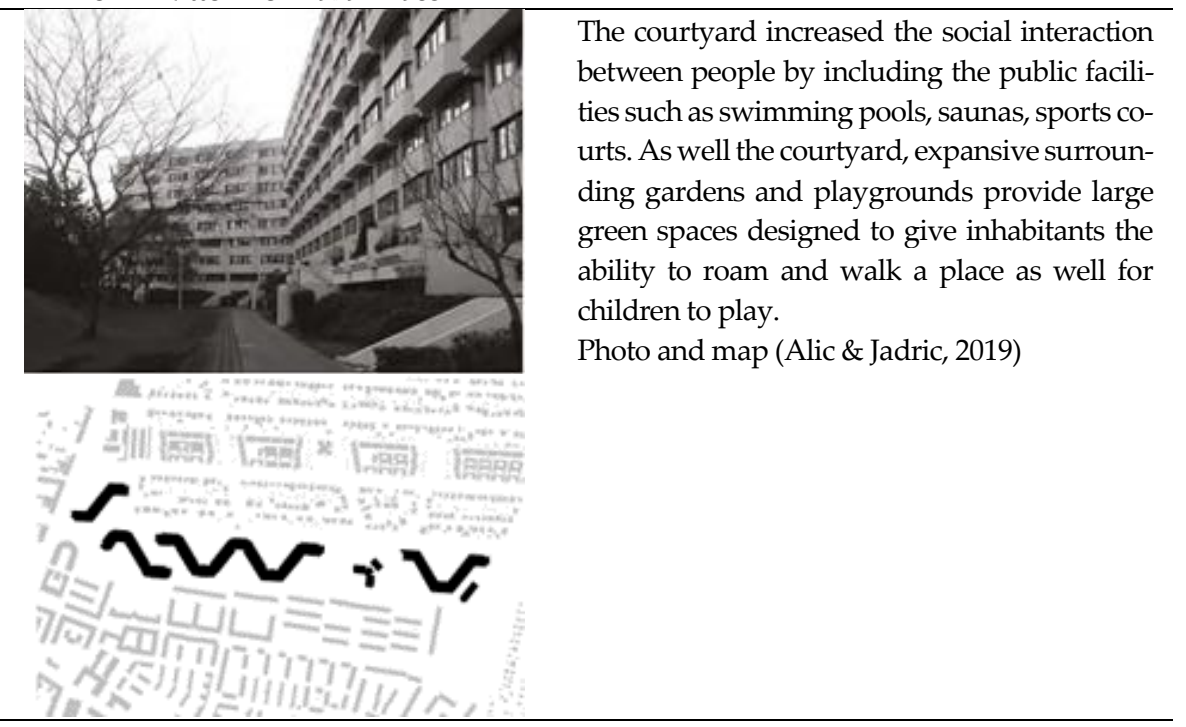




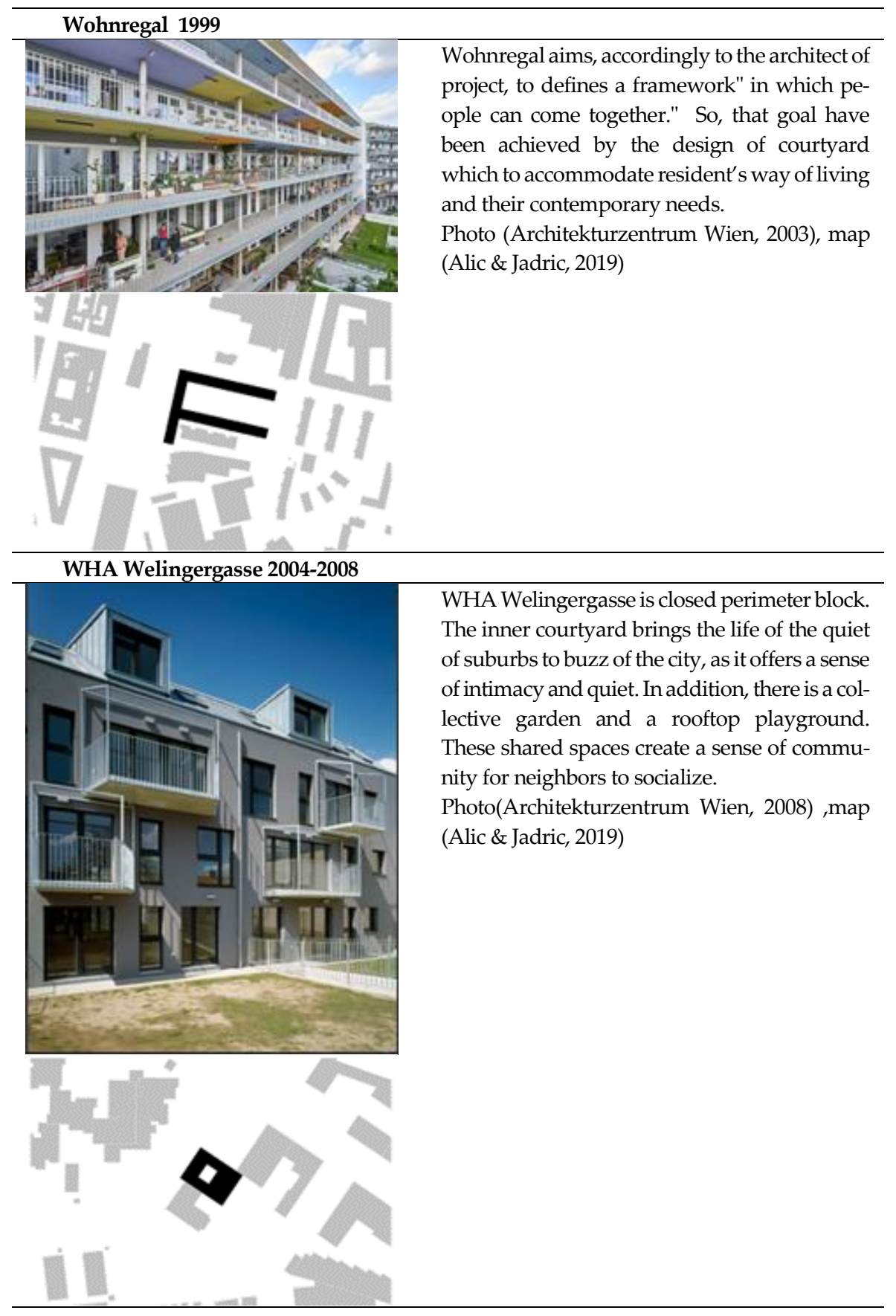




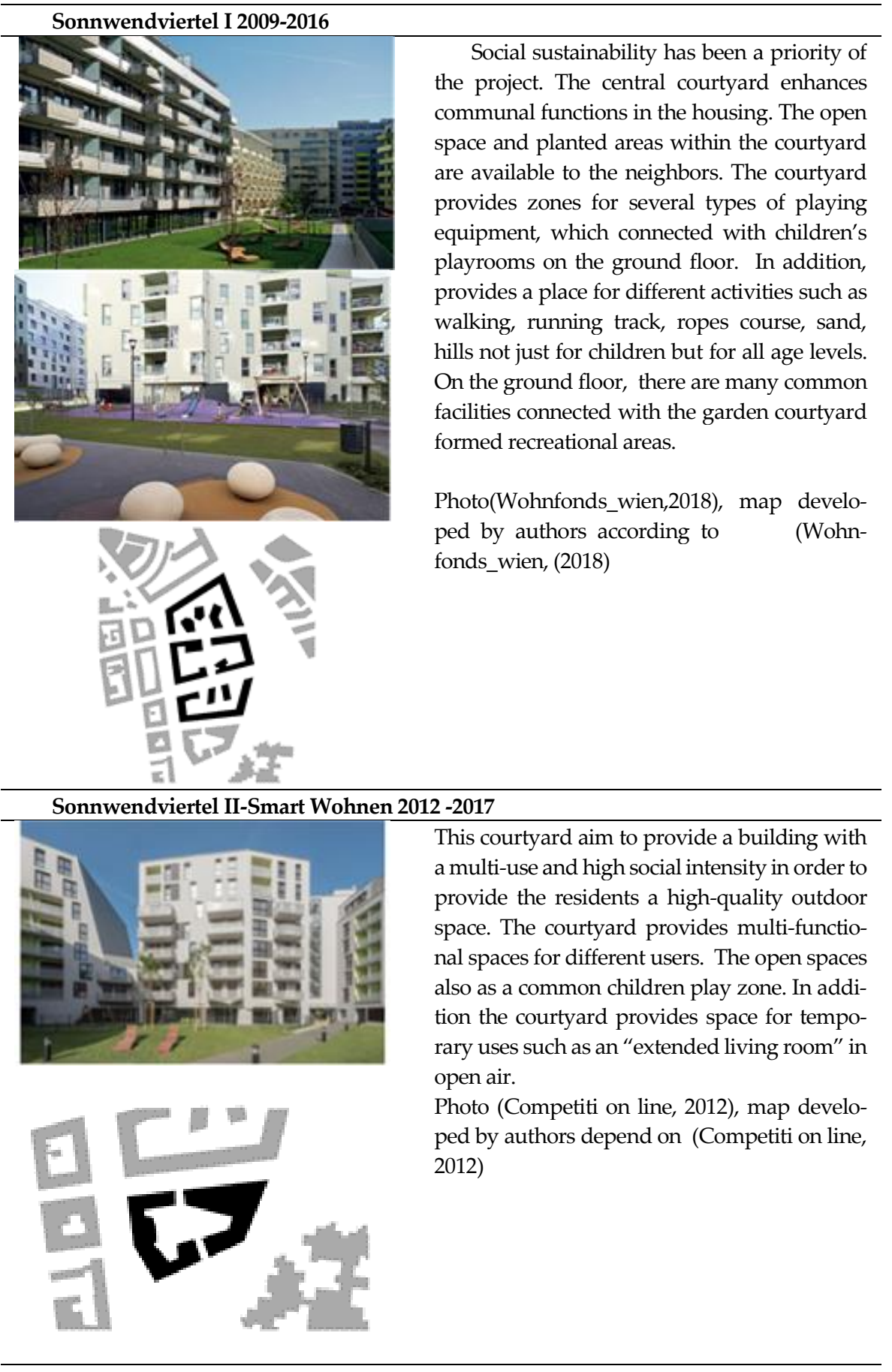



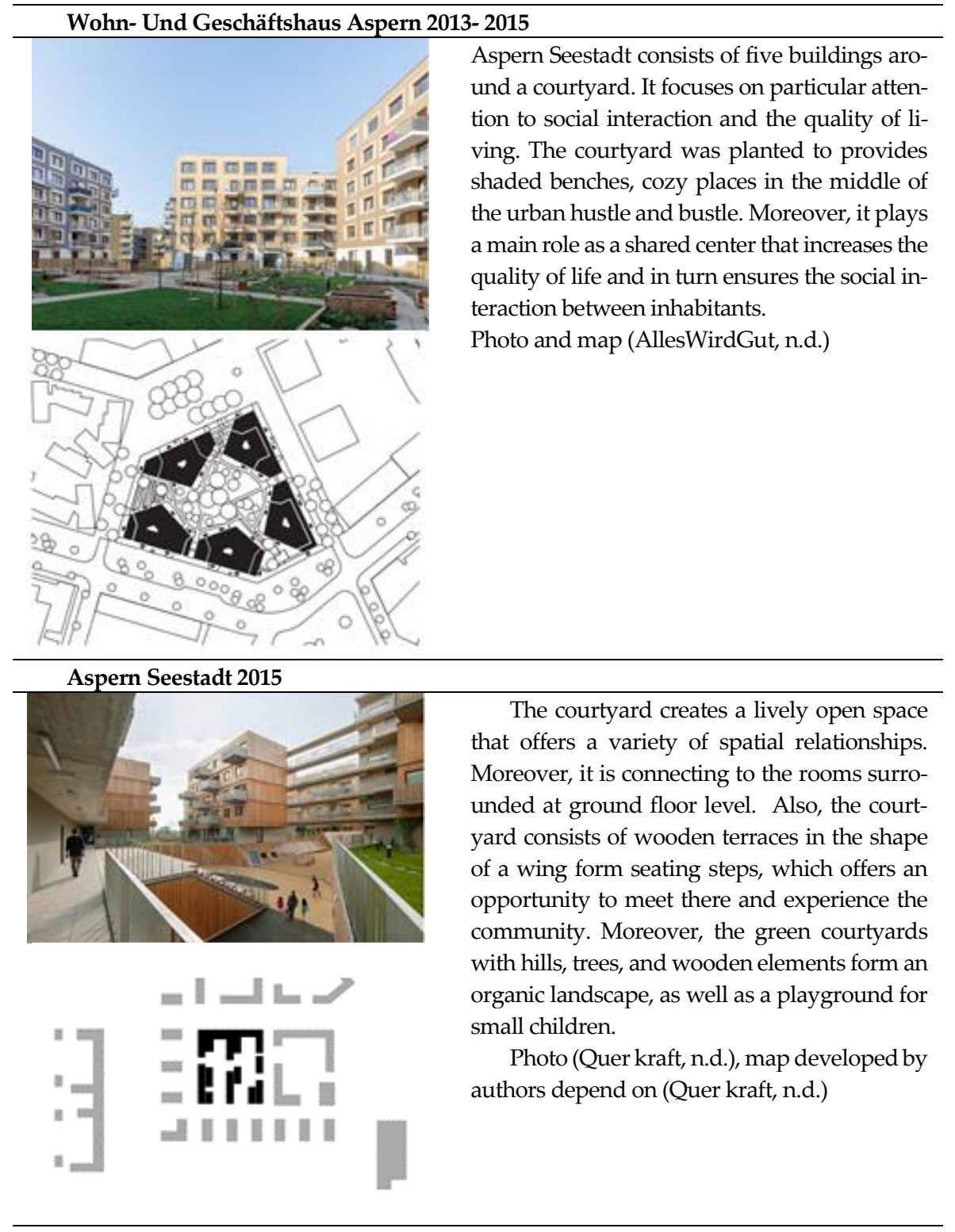


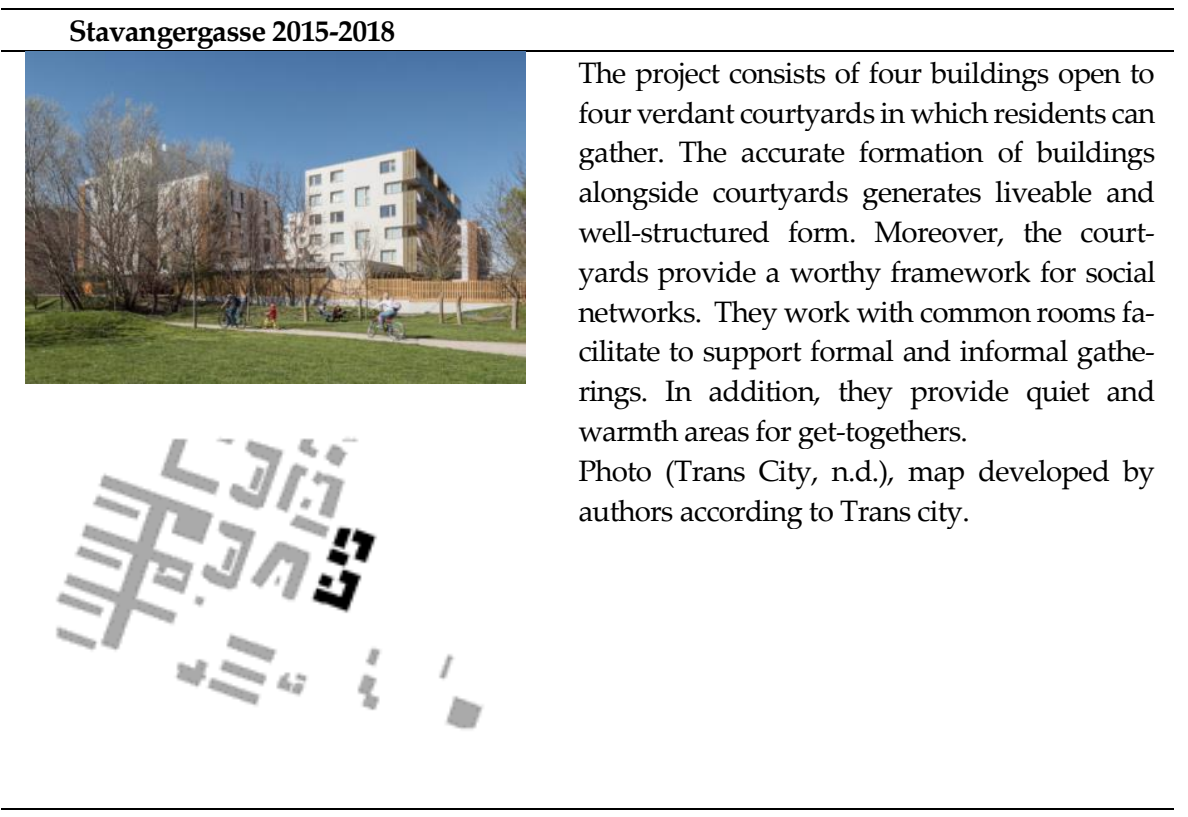

As it has been seen from the examples, the courtyard blocks in Vienna refer to innovation in creating a new method to represent the courtyard in a new product. This innovation is juxtaposed preserving the culture and rituals. Looking at the Syrian context, the examples that have been mentioned give a wide insight to shape a new housing typology using the courtyard as a collective space to bring people together and to think about the collective dimension of the city.

\section{Conclusion}

It is necessary to sustain some architectural codes by adapting them to the changing dynamics and spirit of the age in order to understand the user needs and make design decisions accordingly for sustainable communities. Analysing the codes of the architectural understanding that is desired to be sustained leads architectural understanding in a more meaningful direction. The Syrian courtyard house, with its social and physical meaning, is one of these important features for the after-war urban development. Since this typology is ignored in the modern urban movement despite many advantages in terms of providing a qualified living environment, there is a need of reconsidering contemporary housing development. It is obvious that the low rise characteristic of traditional courtyard housing cannot respond to the demand 
for high density housing in contemporary cities. Since the requirements of urban life changes from the past, an adaptation process of the courtyard house is needed.

In this context, some projects from different periods in Vienna have been analysed and presented in order to reveal how this characteristic phenomenon is used in the design process and how it corresponds. These demonstrate a continuum of the courtyard, which has a great importance for the sustainable communities. This continuum is not just formal, but also social in an improved characteristic. The vision of designing courtyard buildings in Vienna has been to provide a " new collective society and of a new idea of living together" for many years. Vienna has become an internationally renowned example of social integration, demonstrating that this is an absolute prerequisite for and an essential component of a fair, integrated and sustainable city. (Alic \& Jadric, 2019). Considering this success of Vienna in housing, it can be indicated that this is not a coincidence but a result of the consistency in architectural codes and morphologies with a convenient interpretation.

The contemporary courtyard has many characteristics in term of support sense of community, integration, social cohesion. The design of courtyard form deemed overly paternalistic, provides a shared open space, which works as a complementary of the housing units. The housing units that surround a communal courtyard, have a right to control or determine the activity taking place within it. This also helps to develop community sense from an individual when he feels its rights in public space and provides defensible space production.

In this sense Viennese examples with their mutlifunctionality and flexibility of their housing design solutions with courtyard which is also well-connected with indoor social facilities can lead new housing implementations such as after-war Syria redevelopment. Because in these cases the courtyard idea have been moved beyond its formal sense by referring to an enriched content with targeted social cohesion in design. Moreover, demonstration and analyse of these successful experiences in Vienna in terms of adapting courtyard to the modern multi-unit housing, ensure guidelines of knowledge worthy of consideration in terms of design solutions to architects and planners in Syria. The considerations and modern interpretations analysed in the study are relevant to demonstrate practical examples concretely. This provides a potential for the production of wealth of typological experimentations in several ways with a harmony to the existing courtyard idea and urban pattern. The social sustainability which can be supported with good design, a 
crucial need in Post-war housing development in Syria. Since reconstruction is a chance for a qualified and characteristic urban design, Syria should learn from the experience of Vienna.

\section{References}

Abass, F., Ismail, L. H., \& Solla, M. (2016). A review of courtyard house: history evolution forms, and functions. ARPN Journal of Engineering and Applied Sciences, 11(4), 25572563.

Alic, D., \& Jadric, M. (2019). AT HOME IN VIENNAI Zu Hause in Wien: Studies of exemplary affordabel housing I Eine Studie und Sammlung geforderter Wiener Wohnbauten (Vol. 1). TU Wien Academic Press.

Al-Jokhadar, A., \& Jabi, W. (2016). Towards a 'Contemporary Vernacular' high-rise residential development in the Middle-East and North-Africa: Learning from the Socio-Spatial qualities of the vernacular model. Amman, Jordan.

AllesWirdGut. (n.d.). Retrieved from WAS- Social Housing, 170 Units: https://www.awg.at/de/startseite/

Al-Najem, I. (2015, November 07). The Shami wedding... ululating, "Hanahin" and Henna. Retrieved from

E-Syria: http://esyria.sy/sites/code/index.php?site=damascus\&p=stories\&category=commun ity\&filename $=201501071718591$

Al-Sabouni, M. (2017). From a model of peace to a model of conflict: The effect of architectural modernization on the Syrian urban and social make-up. International Review of the Red Cross, 99(906), 1019-1036. Doi:10.1017/S181638311900002X

Al-Sabouni, M., \& Scruton, R. (2016). The Battle for Home: The Vision of a Young Architect in Syria. Thames \& Hudson; Illustrated edition.

Architekturzentrum Wien. (2003, September 14). Next Room. Retrieved July 16, 2021, from Wohnregal Helmut Wimmer - Wien (A) - 1999: https://www.nextroom.at/building.php?id=2874

Architekturzentrum Wien. (2008, June 08). Next Room. Retrieved July 16, 2021, from Wohnhaus Welingergasse Jadric Architektur - Wien (A) - 2007: https://www.nextroom.at/building.php?id=30790

Ayçam, İ., Akalp, S., \& Görgülü, L. S. (2020). The application of courtyard and settlement layouts of the traditional Diyarbakır houses to contemporary houses: A case study on the analysis of energy performance. Energies, 13(3), 587.

Aycam, I., \& Varshabi, N. (2016). The analysis of form, settlement pattern and envelope alternatives on building cooling loads in traditional Yazd houses of Iran. Gazi University Journal of Science, 29(3), 503-514.

Bently, I., Alcock, A., Murrain, P., McGlynn, S., \& Smith, G. (1985). Responsive environments A manual for designers. Oxford 
Competition line. (2012, October 30). Retrieved July 16, 2021, from Wohnanlage Sonnwendviertel II - $\quad$ Smart Wohnen: https://www.competitionline.com/de/beitraege/59921

Edwards, B., Sibley, M., Hakmi , M., \& Land, P. (2006). Courtyard Housing : Past,Present, Future. New York: Taylor \& Francis.

Fathy, H. (2010). Architecture for the poor: an experiment in rural Egypt. University of Chicago press.

Fierlinger, T. (2016). Der Wiener kommunale Wohnbau der Nachkriegszeit am Beispiel der PerAlbin-Hansson Siedlung West (Doctoral dissertation, Wien).

GIBBONS, A. (2019, MAY 25). Red vienna, a visıon of housing. Retrieved from MAY 25, 2019: http:/www.writingcities.com/2019/05/25/red-vienna-a-vision-of-housing/

Hassan, S. A., \& Resen, M. J. (2018). The transformations in the urban fabric of traditional city centers (Lebanese Experience: Case Study). KnE Engineering, 1-15. https://doi.org/10.18502/keg.v3i4.2158

Hatipoğlu, H. K., \& Aytekin, Ç. K. Mimaride tasarım kodları ve anlamsal sürdürlebilirlik: Dil, Bellek ve Kimlik Tartışması. İdealkent, 11(31), 1676-1698.

Jacobs, J. (1992). The death and life of great American cities. 1961. New York: Vintage.

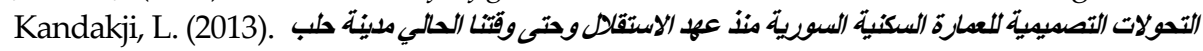
[Design Transformations of Residential Architecture In the Syrian Cities since Independence Till Now : Case study : Aleppo City ].University of Aleppo.

Khalili, S. (2012). The Courtyard House Using cultural references of the past as an alternative to Ottawa's current housing typologies. Ottawa, Ontario: Carleton University.

Lee, M.-S., \& Park, Y. (2015). The Courtyard as a Microcosm of Everyday Life and Social Interaction. Architectural Research, 17(2), 65-74. Doi:http://dx.doi.org/10.5659/AIKAR.2015.17.2.65

Makboul, D. (2016). المدينة العربية الحليثة قراعة سوسيو لسانية في أعراض التعلن [The Modern Arab CityA Socio-Linguistic Reading of Symptoms of Urbanization Phenomena]. Omran. DOI: $10.12816 / 002756$

Mansour, H. (2015). The lost identity of the city: The case of Damascus. In CITTA 8 th Annual Conference on Planning Research AESOP TG Public Spaces \& Urban Cultures Event (p. 1-20).

Monterumisi, C., \& Porotto, A. (2017). Why can't we live together? Stockholm-Vienna's large courtyard blocks. AMPS Proceedings Series 10, 10(CONF).

Nasar, J. L., \& Julian, D. A. (1995). The psychological sense of community in the neighborhood. Journal of the American Planning Association, 61(2), 178-184.

Nikeghbali, S. (2017). Adapting design principles of traditional courtyard housing for future urban design. Journal of Sustainable Development, 10(6).

Pelleteret, L. (2020). "Housing is a Human Right, Not a Business". Les Cahiers de la recherche architecturale urbaine et paysagère. doi:DOI: 10.4000/craup.5202

Petruccioli, A. (2007). After Amnesia. Learning from the Islamic Mediterranean Urban Fabric. ICAR. 
Pomeroy, J. (2020). Cities of Opportunities Connecting Culture and Innovation. London. doi:https://doi.org/10.4324/9781003022299

Porotto , A. (2019). Wealth of Typological Solutions from the Twenties: Vienna and Frankfurt. II Congreso Internacional Cultura y Ciudad. La Casa. Espacios domésticos, modos de habitar. Granada, Spain: ETSAG Escuela Técnica Superior de Arquitectura, Universidad de Granada. Retrieved from https:/www.researchgate.net/publication/331971334_A_Wealth_of_Typological_S olutions_from_the_Twenties_Vienna_and_Frankfurt

Porotto, A. (2016). Utopia and Vision. Learning from Vienna and Frankfurt. Joelho, 84103. doi:10.14195/1647-8681_7_7

Porotto, A. (2017). Kleinwohnung vs Existenzminimum: Social housing types from inter-war years. In ATINER'S Conference Paper Series (No. CONF). Athens Institute for Education and Research.

Quer kraft. (n.d.). Retrieved from Wood Housing Seestadt Aspern / Berger+Parkkinen Architekten + Querkraft: https://www.querkraft.at/projekte/asp-holzwohnbau

Salman, M. (2018). Sustainability and vernacular architecture: Rethinking what identity is. In Urban and Architectural Heritage Conservation within Sustainability. IntechOpen. DOI: 10.5772/intechopen.82025

Tafuri, M. (1985). Architettura e Realismo. In V. Magnago Lampugnani (Ed.), Architettura moderna: L'avventura delle idee 1750-1980, (p. 123-145).Milano: Electa

Taleghani, M. (2014). Dwelling on Courtyards Exploring the energy efficiency and comfort potential of courtyards for dwellings in the Netherlands.

Trans City. (n.d.). Retrieved from Stavangergasse zwei+plus: an intergenerational network: https://trans-city.at/tc/portfolio/stavangergasse/?lang=en

Wien Geschichte Wiki. (2021, April 24). Retrieved July 16, 2021, from George-WashingtonHof: https://www.geschichtewiki.wien.gv.at/George-Washington-Hof

Wohnfonds_wien. (2018, November). Wohnfonds_wien. Retrieved from sonnwendviertel subsidised living in a new urban district: http://www.wohnfonds.wien.at/media/Website\%20PDF-

INFO\%20Downloads/English\%20Information/Broschure_Sonnwendviertel_2018_ englisch_web.pdf

Zein Alabidin, M. (2010, March 9). The courtyard houses of Syria. Retrieved from Muslim heritage: https:/muslimheritage.com/the-courtyard-houses-of-syria/ 